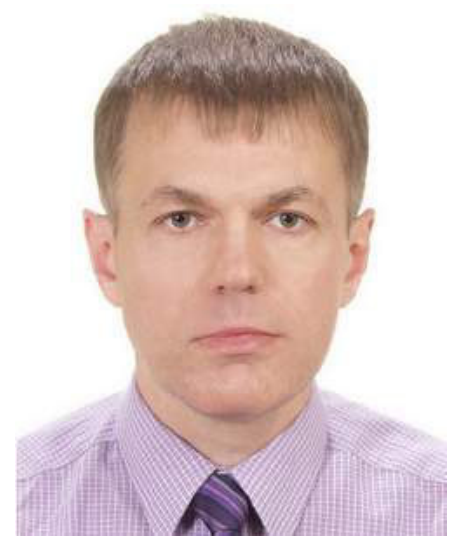

Юрій Бойчук,

доктор педагогічних наук, профресор,

завідувач кафедри спеціальної,

інклюзивної і здоров'язбережувальної освіти,

ХНПУ імені Г.С.Сковороди

(м. Харків, Україна)

Yuri Boychuk,

Doctor of Education, Professor,

Head of Special, Inclusive and Health-saving

Education Department,

Kharkiv National Pedagogical University

named after H. S. Skovoroda,

(Kharkiv, Ukraine)

yurij.boychuk@gmail.com

ORCID ID: 0000-0003-4842-3857

\title{
Олена Казачінер,
}

кандидат педагогічних наук, старший викладач кафредри методики навчання мов і літератури, КВН3 «Харківська академія неперервної освіти» (м. Харків, Україна)

\section{Elena Kazachiner,}

$\mathrm{PhD}$ in Education, senior lecturer of Methods

of Teaching Languages and Literature Department,

Kharkiv Academy of Postgraduate Education

(Kharkiv, Ukraine)

\section{СТВОРЕННЯ ІНКЛЮЗИВНОГО ОСВІТНЬОГО СЕРЕДОВИЩА НА УРОКАХ ІНОЗЕМНОÏ (АНГЛІЙСЬКОї) МОВИ В ПОЧАТКОВІЙ ШКОЛІ}

Анотація. У статті визначено, що одним із фундаментальних положень нового Державного стандарту початкової освіти та пріоритетних завдань Нової української школи є формування інклюзивного освітнього середовища в закладах загальної середньої освіти.

Вивчення особливостей створення комфортного інклюзивного освітнього середовища має важливе значення для успішного виховання та соціалізації не тільки дітей з порушеннями психофізичного розвитку, а й інших учнів, особливо молодших школярів.

Метою дослідження $€$ визначення особливостей створення інклюзивного освітнього середовища на уроках іноземної (англійської) мови в початковій школі.

Методами наукового пошуку є систематизація, аналіз, синтез наявного в науково-педагогічній літературі матеріалу з теми дослідження, а також висвітлення власного педагогічного досвіду з окресленої проблеми.

На основі аналізу науково-педагогічної літератури у статті визначено зміст понять «освітнє середовище», «корекційне середовище», «інклюзивне освітнє середовище»; окреслено характерні риси інклюзивного освітнього середовища, його переваги для дітей із особливостями психофрізичного розвитку; на підґрунті власного педагогічного досвіду висвітлено форми, методи та прийоми навчання іноземної (англійської) мови в початковій школі в інклюзивному освітньому середовищі. Встановлено, що під час занять 3 іноземної мови 3 дітьми $з$ особливими освітніми потребами в початкових класах педагогом на перше місце висувається завдання щодо розвитку мислення, пам'яті, мовлення, активізації пізнавальної діяльності, збагачення дитини знаннями про навколишній світ, чому іноземна мова сприяє як ніякий інший предмет.

Ключові слова: інклюзивне навчання; інклюзивне освітнє середовище; діти з особливими освітніми потребами; уроки іноземної мови; початкова школа.

\section{CREATION OF INCLUSIVE EDUCATIONAL ENVIRONMENT AT THE LANGUAGE (ENGLISH) LESSONS IN PRIMARY SCHOOL}

Abstract. The article states that one of the fundamental provisions of the new State Standard of Primary Education and the priority tasks of the New Ukrainian School is formation of the inclusive educational environment in general educational establishments. 
The study of the peculiarities of creating comfortable inclusive educational environment is important for successful education and socialization of not only children with disorders of psychophysical development but also other students. It is especially important for primary schoolchildren.

The purpose of the study is to determine the features of creating inclusive educational environment at the foreign (English) language lessons in primary school.

The methods of scientific research are systematization, analysis, synthesis of available material in scientific and pedagogical literature on the topic of research, as well as coverage of own pedagogical experience on the outlined problem. On the basis of scientific and pedagogical literature analysis, the content of the concepts "educational environment»,

«correctional environment», «inclusive educational environment» was determined in the article; the features of inclusive educational environment, its advantages for children with peculiarities of psychophysical development were outlined; on the basis of own pedagogical experience, the forms, methods and methods of teaching foreign (English) language in primary school in inclusive educational environment are highlighted.

It was determined that during foreign language lessons with children with special educational needs in primary school, the teacher puts the emphasis on the development of thinking, memory, speech, activating cognitive activity, enriching the child with knowledge of the world around him, what a foreign language promotes as no other subject.

Keywords: inclusive education; inclusive educational environment; children with special educational needs; foreign language lessons; primary school.

\section{ВСТуп}

Постановка проблеми. Одним із фундаментальних положень нового Державного стандарту початкової освіти та пріоритетних завдань Нової української школи є фрормування інклюзивного освітнього середовища як інноваційного в закладах загальної середньої освіти.

Ученими обговорюються проблеми інтеграції дітей з особливими освітніми потребами і активно розробляються підходи до навчання та виховання їх в умовах закладів загальної середньої освіти. Вивчення особливостей створення комфортного інклюзивного освітнього середовища має важливе значення для успішного виховання та соціалізації не тільки дітей з порушеннями психофізичного розвитку, а й інших учнів, для створення ситуації успіху для кожної без виключення дитини. Особливо важливим це є для молодших школярів, оскільки саме в початковій школі мають закладатися основи успішного опанування знань, умінь та навичок.

Аналіз останніх досліджень і публікацій. Дослідженню проблем освітнього середовища присвячено численні роботи вітчизняних і зарубіжних учених (Я. Корчак, В. Ясвін, Г. Ковальов та інші). Питання створення, розвитку та оцінювання інклюзивного освітнього середовища в закладах загальної середньої освіти розглянуто І. Бочковською, С. Гайдукевич, Г. Єфремовою, О. Козирєвою, М. Ковальовою, Н. Малофеєвим, О. Сакалюк та іншими.

\section{МЕТА І ЗАВДАННЯ ДОСЛІДЖЕННЯ}

Метою дослідження $є$ визначення особливостей створення інклюзивного освітнього середовища на уроках іноземної (англійської) мови в початковій школі.

Відповідно до мети нами було сформульовано такі завдання дослідження:

1) на основі аналізу науково-педагогічної літератури визначити зміст поняття «інклюзивне освітнє середовище»;

2) окреслити характерні риси інклюзивного освітнього середовища, його переваги для дітей із особливостями психофрізичного розвитку;

3) на підґрунті власного педагогічного досвіду висвітлити фрорми, методи та прийоми навчання іноземної (англійської) мови в початковій школі в інклюзивному освітньому середовищі.

МЕТОДИ ДОСЛІДЖЕННЯ: систематизація, аналіз, синтез наявного в науково-педагогічній літературі матеріалу з теми дослідження, а також висвітлення власного педагогічного досвіду з окресленої проблеми.

\section{РЕЗУЛЬТАТИ ДОСЛІДЖЕННЯ}

У загальній педагогіці під «освітнім середовищем» розуміють систему впливів і умов формування особистості, а також можливості для її розвитку, які містяться в соціальному і просторово-предметному оточенні.

У спеціальній педагогіці поширене поняття «корекційне середовище», під яким розуміють системне об'єднання медичних, психолого-педагогічних і соціальних служб, що сприяють саморегуляції поведінки, самореабілітації, розвитку і саморозвитку особистості [5]. Його метою є забезпечення умов для максимально можливої корекції та компенсації окремої чи комбінованої вади, здійснення профілактичних заходів через залучення кожної дитини до спеціально створеного реабілітаційного, розвивального і соціально-культурного середовища.

Чіткою та аргументованою вважаємо думку О. Рассказової та К. Рєзник, які визначають інклюзивне освітнє середовище як сукупність об'єктивних зовнішніх умов, фракторів, соціальних об'єктів, необхідних для успішного навчання та виховання дітей з особливими потребами [6].

Схоже визначення інклюзивного середовища подає І. Кузава: це життєвий простір, що забезпечує підвищення почуття власної гідності та впевненості у собі дітей, які потребують корекції психофрізичного розвитку. Створення інклюзивного середовища, на думку автора, являє собою гнучку, індивідуалізовану систему, що передбачає не лише пристосування фізичного середовища, але й підготовку педагогів, зміну системи надання вихованцям можливості навчатись за індивідуальним навчальним планом, забезпечення медико-соціального, психолого-педагогічного та наукового супроводу, створення навчальних програм, навчально-методичного забезпечення тощо [4].

Мету цього середовища І. Калініченко вбачає в орієнтуванні на розвиток особистості та відповідність запитам соціального оточення і сподіванням людини [3].

Провідним принципом інклюзивного середовища є можливість пристосовуватись до індивідуальних потреб різних категорій дітей за рахунок структурно-функціональної, змістовної та технологічної модернізації освітньої системи закладу, здійснення індивідуального підходу, гуманних стосунків з кожною дитиною, проведення занять у формі ігрової діяльності [2]. 
Заслуговує на увагу зміст поняття «інклюзивний дизайн» (inclusive design), «за допомогою якого створюється середовище, в якому кожний може отримати доступ і отримати вигоду від повного ряду можливостей, доступних для членів суспільства. Він має на меті усунути перешкоди, які створюють надмірні зусилля, розділення, і дозволяє кожному, незалежно від інвалідності, віку або статі, брати участь у рівній мірі, впевнено і незалежно в основній діяльності з вибором і гідністю. Інклюзивний дизайн - це гарний дизайн, і він є основоположним для досягнення високої якості життя для всіх нас» [10, с. 7].

В інклюзивному середовищі люди всіх культурних орієнтацій можуть: вільно висловлюватися, хто вони, викладати свої думки та погляди; в повному обсязі брати участь у викладанні, навчанні, праці та суспільній діяльності; почувати себе в безпеці від зловживань, переслідувань або несправедливої критики [9].

Сучасними зарубіжними вченими (Є. Гончарова, Т. Зубарєва, О. Кукушкіна, М. Малоффєєв, О. Нікольська, Н. Шматко) визначено основні ознаки інклюзивного середовища: 1) культивування системи ціннісного ставлення до навчання, виховання та особистісного розвитку дітей з психофізичними порушеннями, наявність ресурсного забезпечення їх життєдіяльності; 2) визначення та реалізація фрілософії інклюзії, ролі освітнього закладу в галузі важливих функцій інклюзивної діяльності, загальних підходів та принципів життєдіяльності вихованців з обмеженими можливостями здоров'я, а також оптимальної структури освітнього процесу; 3) задоволення освітніх потреб дітей; 4) створення умов для організації безбар'єрного освітнього процесу з урахуванням особливих потреб; 5) створення індивідуальноорієнтовних програм з урахуванням внесення змін щодо освітніх можливостей кожної дитини; 6) колективне формування інклюзивного середовища; 7) система діяльності психолого-медико-педагогічних консультацій.

У психолого-педагогічній науці визначено основні компоненти інклюзивного середовища (безбар'єрне фізичне і психічне середовище, спеціальні умови навчання і виховання), а також критерії його успішного розвитку (збільшення в освітньому закладі не лише частки дітей з особливими потребами, але й їх здорових однолітків, рівні можливості в отриманні педагогічної корекції і психологічної підтримки для всіх вихованців, відкритість і доступність інклюзивного середовища як для дітей, так і для їх батьків) [4].

Таким чином, серед першочергових кроків у напрямі створення інклюзивного середовища вбачаються такі: відмовитися від стереотипних поглядів на вчителів, учнів і освітній процес; фрормувати в школі атмосферу, засновану на ідеях інклюзії; розбудувати школу як громаду; зосереджуватися на співпраці, а не на конкуренції; прищеплювати віру в свої сили кожному члену шкільного колективу [7].

В інклюзивному освітньому середовищі всі діти здатні досягати успіху. На основі всебічного аналізу літератури з цього питання Д. Мак Грегор і Фогельсберг наводять такі переваги для дітей із особливими освітніми потребами: вони демонструють вищий рівень соціальної взаємодії з іншими дітьми, які таких обмежень не мають; підвищується соціальна компетентність і вдосконалюються комунікативні навички; діти з особливими потребами навчаються за складнішою й глибшою навчальною програмою, завдяки чому процес набуття вмінь і навичок протікає ефективніше, а академічні досягнення покращуються; посилюється соціальне сприйняття дітей з відмінними здібностями. Дослідження довели, що діти в інклюзивному закладі мають надійніші й триваліші зв'язки з друзями, ніж діти в сегрегованому середовищі [3].

Власний педагогічний досвід навчання іноземної (англійської) мови в початковій школі свідчить про те, що діти з певними особливостями психофрізичного розвитку, порушеннями аналізаторів мають певні ускладнення під час вивчення даного предмету.

Цілком очевидним є той фракт, що дитина з обмеженими можливостями може відчувати певні труднощі в процесі вивчення іноземної мови, наприклад, труднощі із засвоєнням нових лексичних одиниць, граматичних та синтаксичних конструкцій, аудіюванням (труднощі фонематичного характеру унеможливлюють диференціацію схожих звуків). Але навчання іноземної мові дітей з порушеннями здоров'я сьогодні є особливо актуальним через те, що в наш час не стільки важливо дати дитині якомога більший багаж знань, скільки забезпечити її загальнокультурний, особистістний і пізнавальний розвиток, озброїти таким важливим умінням, як уміння вчитися. Таким чином, під час занять з іноземної мови 3 дітьми 3 особливими освітніми потребами в початкових класах педагогом на перше місце висувається завдання щодо розвитку мислення, пам'яті, мовлення, активізації пізнавальної діяльності, збагачення дитини знаннями про навколишній світ, чому іноземна мова сприяє як ніякий інший предмет. У цьому аспекті практичне володіння мовою стає не метою, а засобом розв'язання завдання.

Використовуючи інформаційно-комунікаційні технології, дитина з особливими освітніми потребами із задоволенням та бажанням опановує іноземну мову. Використання ігрових програм, CD-дисків, SMART-дошки, перегляд відеофільмів, мультфільмів допомагає дитині швидше та легше запам'ятовувати запропонований учителем матеріал, що допомагає розширити кругозір та знання учня. Завдяки цьому в дитини виникає відчуття, що її зусилля не марні.

Навчити дитину з особливими освітніми потребами іноземної мови - це складний і тривалий процес, але результат цього процесу ще раз доводить, що всі діти можуть бути успішними, якщо їм своєчасно надати необхідну освітню допомогу.

Так, у навчанні іноземної (англійської) мови молодших школярів із легкими порушеннями зору на уроках нами здійснювалося: залучення учнів до малювання, виготовлення літер із різних матеріалів (пластиліну, паличок, стрічок тощо); ігри на відгадування («Чарівний мішечок»), у яких діти за допомогою обмацування виготовлених із пластиліну літер відгадували їх (схожа гра була використана й під час вивчення тем «Шкільне приладдя», «Одяг»). Цікавим видом роботи, який періодично застосовувався нами на уроках, є малювання пластиліном картини учнями в парах із додержанням рамок малюнка з метою розвитку дрібної моторики, співвіднесення кольорів. Після цього діти залучалися до складання усної або письмової розповіді за малюнком. 
Розвиток дрібної моторики руки, тактильної чутливості, координації «око-рука», формування графомоторних навичок здійснювалися й шляхом виконання школярами так званих tracing activities, тобто обведення за зразком ліній, елементів літер, великих та рядкових літер, слів та речень, а також за допомогою виконання вправ пальчикової гімнастики, роботи з іграшками з кіндер-сюрпризів, фрактурними фігурками Stikeez, мозаїкою. Крім того, за допомогою цих іграшок вивчалася тема «Тварини», назви кольорів іноземною мовою, створювалися сюжетні розповіді.

Гофрований папір, яскравий, шорсткий, фактурний, допомагає стимулювати сенсорні системи дітей; він $є$ корисним для фрормування й розвитку зорових, дотикових, слухових чуттів і також може з успіхом застосовуватися в процесі навчання іноземних мов.

Для забезпечення опанування учнями з легкими порушеннями зору навички читання нами пропонувалися тексти зі збільшеним та більш яскравим шрифтом, які набиралися на комп'ютері та роздруковувалися; 3 метою розвитку просторової орієнтації - під час ознайомлення учнів із прийменниками місця та напряму використовувалися дидактичні ігри на пошук того чи іншого предмета, захованого в класі.

3 метою тренування візуального сприймання цією категорією учнів нами розроблялися завдання на зіставлення предметів з їх зображенням, на розрізнення зображень та класифікації їх за категоріями, наприклад Food, Drinks, Kitchen utensils.

Цікавою формою роботи на уроках є створення та використання інтерактивного й багатофрункціонального календаря, який сприяє, крім вивчення назв пір року, днів тижня, місяців, дат, розвиткові дрібної моторики, візуального сприймання, пам'яті, набуттю дітьми соціальних навичок.

Щодо роботи з дітьми з легкими порушеннями слуху та з легкими мовленнєвими розладами, нами здійснювався розвиток їхнього фонетико-фонематичного сприймання за допомогою таких фрорм, методів та прийомів: 1) ігор на відгадування звука, який вимовляється, по губах; 2) ігор та вправ на диференціацію схожих приголосних та довгих / коротких голосних звуків у словах; 3) написання слів, які мають складну орфографію, за зразком, пояснення їх значення, розвитку мовлення шляхом складання речень із цими словами; 4) створення лінгвістичних навчальних казок, де мова йде про слова, значення яких змінюється від однієї літери; 5) використання артикуляційної, дихальної гімнастики; 6) використання елементів логоритміки; 7) надування повітряних кульок із метою розвитку мовленнєвого дихання й подальшого вивчення назв кольорів.

Під час вивчення іноземної (англійської) мови діти з затримкою психічного розвитку (ЗПР) зазнають певних ускладнень: уповільнено відбувається засвоєння лексичного матеріалу, синтаксичних конструкцій та активне застосування їх в усному мовленні; ускладнене сприймання граматичних категорій та застосування їх на практиці. Граматично складно побудоване мовлення їм не засвоїти, оскільки ступінь навченості іноземної мови залежить від загального рівня розвитку дитини. Але ці діти зможуть опановувати іншу мову на рівні свого розвитку.

Для таких учнів характерним $є$ виникнення проблем під час аудіювання, особливо зв'язних текстів, діалогічного мовлення, оскільки в них спостерігаються труднощі звукового аналізу й фонематичного слуху. Вони нечітко сприймають звернене мовлення, не диференціюють схожі звуки. Діти з діагнозом ЗПР оволодівають основними видами мовленнєвої діяльності: читанням, говорінням (усним мовленням), аудіюванням. Письмо на всіх етапах навчання використовується лише як засіб навчання.

В основі навчання дітей із ЗПР лежить навчання читання, в закладі загальної середньої освіти навчання базується на усній основі. Основна мета вивчення іноземної мови в таких класах - розвивальна, «не знання, а розвиток». Тому на уроках іноземної мови необхідно розвивати в учнів пам'ять, мовлення, сприймання, мислення та кругозір.

У власній педагогічній практиці навчання іноземної мови молодших школярів, які мають порушення інтелектуального розвитку, нами було застосовано такі форми, методи та прийоми: 1) цікаві дидактичні вправи й завдання, метою яких було навчання учнів диференціювати слова зі схожими звуками та літерами; 2) спрощення вимог до подання граматичних конструкцій; 3) забезпечення покрокового формування навичок мовленнєвої діяльності; 4) широке використання наочності, комп'ютерних навчальних програм під час презентації мовного матеріалу.

Застосування середовищного підходу в навчанні дітей з особливими освітніми потребами дозволило дослідникам сформулювати низку вимог, що забезпечують специфіку організації та реалізації цього процесу: 1) у більшості випадків проблему варто шукати не в дитині, а в середовищі, що її оточує (на рівні сім'ї, класу, школи і т. ін.), тобто ії обмеження зумовлені середовищем; 2) якщо в дитини є особливі потреби, то вона включається в освітнє середовище на своїх власних умовах (не дитина пристосовується до середовища, а середовище до дитини); 3) визначення цих умов забезпечується за рахунок виявлення перешкод, що обмежують життєдіяльність дитини на всіх рівнях (знаходити і пізнавати предмети, оцінювати величини і відстані, здійснювати просторове орієнтування, запам'ятовувати послідовність дій, працювати в певному темпі, встановлювати та підтримувати контакти, планувати свою діяльність тощо); 4) профілактика, усунення або послаблення перешкод може здійснюватися за рахунок певних перетворень в освітньому середовищі [1]. Таким чином, проведене нами дослідження підтверджує гіпотези інших науковців.

\section{ВИСНОВКИ ТА ПЕРСПЕКТИВИ ПОДАЛЬШИХ ДОСЛІДЖЕНЬ}

Отже, на основі аналізу науково-педагогічної літератури поняття «інклюзивне освітнє середовище» було визначено як середовище, де всі учні незалежно від свої освітніх потреб здатні навчатися ефективніше, підвищувати свою соціальну компетентність, удосконалювати комунікативні навички, а також відчувати себе частиною спільноти. Аргументи на користь перебування учнів в інклюзивному освітньому середовищі незаперечні. Тому супротивне твердження про те, що решта дітей отримують менш якісну освіту в інклюзивному середовищі чи опиняються у менш сприятливих соціальних умовах, складно назвати аргументованим. 
Усі діти, перебуваючи в інклюзивному середовищі, можуть навчитися цінувати й поважати дітей з відмінними здібностями. Вони навчаються бачити людину, а не передусім її ваду чи обдарованість, та не помічати пов'язаних із ними соціальних ярликів.

На підґрунті власного педагогічного досвіду нами було висвітлено фрорми, методи та прийоми навчання іноземної (англійської) мови в початковій школі в інклюзивному освітньому середовищі для дітей із легкими порушеннями зору, слуху, мовлення, інтелектуальної діяльності.

Проте проведене дослідження не вичерпує всіх аспектів проблеми. Перспективним, на нашу думку, може бути окреслення фрорм, методів та прийомів навчання іноземної (англійської) мови в початковій школі в інклюзивному освітньому середовищі дітей інших нозологій (наприклад, із порушеннями опорно-рухового апарату, тощо), а також пошук шляхів створення інклюзивного освітнього середовища на уроках іноземної мови через ознайомлення молодших школярів із творами дитячого фольклору, казками, прислів'ями, приказками народу, мова якого вивчається.

\section{СПИСОК ВИКОРИСТАНИХ ДЖЕРЕЛ}

[1] Державний стандарт початкової освіти (постанова Кабінету Міністрів України від 21 лютого 2018p. № 87). URL: https:// www.pedrada.com.ua/article/2107-priynyato- derjavniy-standart-pochatkovo-osvti?ustp=W

[2] Зубарева Т. Г. Компетентностно-ориентированное повышение квалификации специалистов по созданию инклюзивной образовательной среды. Автореф. дисс. на соискание науч. степени канд. пед. наук. Курский государственный университет, Курск, 2009.

[3] Калініченко І. О. Особливості формування інклюзивного освітнього середовища для забезпечення всебічного розвитку дитини. Актуальні проблеми навчання та виховання людей з особливими потребами: зб. наук. пр. 2012. № 9 (11). С. $120-126$.

[4] Кузава І. Б. Роль інклюзивного середовища у фрормуванні особистості дошкільників, які потребують корекції психофізичного розвитку. URL: http://irbis-nbuv.gov.ua/cgi-bin/irbis_nbuv/cgiirbis_64.exe?C21COM=2\& I21DBN=UJRN\&P21DBN=UJRN\&IMAGE_ FILE_DOWNLOAD=1\&Image_file_name = PDF /znnppo_2012_11_60.pdf

[5] Мастюкова Е. М. Лечебная педагогика. Ранний и дошкольный возраст. М.: ВЛАДОС, 1997. 304 с.

[6] Рассказова О. І., Рєзнік К. М. Інклюзивне освітне середовище як простір соціального виховання молодших школярів. URL: archive.kpi.kharkov.ua/files/17039

[7] Таранченко О.М. Тенденції сучасної освіти: роль педагога у створенні ефективної інклюзивної школи. Дефектологія. Особлива дитина: навчання і виховання. №1 (59). 2011. С. 18-24.

[8] Управління педагогічними інноваціями в інклюзивній освіті : [навч. посіб.] / А. М. Ананьєв, С. В. Воронова, М. В. Малік, О. О. Сакалюк, М. М. Тодорова, М. М. Торган, Н. М. Черненко [та ін.] ; за заг. наук. ред. С. К. Хаджирадєвої. К. : Освіта України, 2014.244 с.

[9] General Information Folio 1. Culturally Inclusive Environment. URL: https://learn.scu.edu.au/bbcswebdav/orgs/HRPLP/cultural_ competency/flinders_toolkit/pdf/General_Information/4334\%20Culturally\%20Inclusive\%20Environment_FINAL_20130418.pdf

[10] Shaping neighborhoods accessible London: achieving an inclusive environment. Supplementary planning guidance. URL: https:// www.london.gov.uk/sites/default/files/shaping_neighbourhoods_accessible_london_spg_2014.pdf

\section{REFERENCES (TRANSLATED AND TRANSLITERATED)}

[1] Derzhavnij standart pochatkovoji osviti (postanova Kabinetu Ministriv Ukrajini vid 21 ljutogo 2018 r. № 87) (State Standard of Primary Education) . URL: https://www.pedrada.com.ua/article/2107-priynyato-derjavniy-standart-pochatkovo- osvti?ustp=W

[2] Zubareva T. G. Kompetentnostno-orientirovannoe povyshenie kvalifikacii specialistov po sozdaniju inkljuzivnoj obrazovatel'noj sredy (Competency oriented postgraduate education of specialists devoted to inclusive educational environment creation). Avtoref. diss. na soiskanie nauch. stepeni kand. ped. nauk. Kurskij gosudarstvennyj universitet, Kursk, 2009.

[3] Kalinichenko I. O. Osoblyvosti formuvannja inkljuzyvnogo osvitn'ogo seredovyshha dlja zabezpechennja vsebichnogo rozvytku dytyny. Aktual'ni problemy navchannja ta vyhovannja ljudej z osoblyvymy potrebamy (Peculiarities of forming inclusive educational environment for full development the child's personality. Actual problems of teaching and upbringing people with special needs): zb. nauk. pr. 2012. № 9 (11). S. 120-126.

[4] Kuzava I. B. Rol' inkljuzyvnogo seredovyshha u formuvanni osobystosti doshkil'nykiv, jaki potrebujut' korekcii' psyhofizychnogo rozvytku (The role of inclusive environment in forming the personality of preschool children who need correction of psychophysical development). URL: http://irbis-nbuv.gov.ua/cgi-bin/irbis_nbuv/cgiirbis_64.ehe?C21COM=2\&I21DBN=UJRN\&P21DBN=UJRN\&I MAGE_FILE_DOShNLOAD=1\&Image_file_name = PDF /znppo_2012_11_60.pdf

[5] Mastjukova E. M. Lechebnaja pedagogika. Rannij i doshkol'nyj vozrast. (Curative pedagogy. Early and preschool age). M.: VLADOS, 1997. $304 \mathrm{~s}$.

[6] Rasskazova O. I., Rjeznik K. M. Inkljuzyvne osvitne seredovyshhe jak prostir social'nogo vyhovannja molodshyh shkoljariv (Inclusive educational environment as a space of primary schoolchildren's social upbringing). URL: archive.kpi.kharkov.ua/files/17039

[7] Taranchenko O.M. Tendencii' suchasnoi' osvity: rol' pedagoga u stvorenni efektyvnoi' inkljuzyvnoi' shkoly (Tendencies of modern education: the role of teacher in creation the effective inclusive school) // Defektologija. Osoblyva dytyna: navchannja i vyhovannja. №1 (59). 2011. S. 18-24.

[8] Upravlinnia pedahohichnymy innovatsiiamy $v$ inkliuzyvnii osviti (Management of pedagogical innovations in inclusive education) / Ananiev, A. M., Voronova, S. V., Malik, M. V., Sakaliuk, O. O., Todorova, M. M., Torhan, M. M., Chernenko, N. M. et al. S. K. Khadzhyradeva (Ed.). Kyiv: Osvita Ukrainy, 2014.

[9] General Information Folio 1. Culturally Inclusive Environment. URL: https://learn.scu.edu.au/bbcswebdav/orgs/HRPLP/cultural_ competency/flinders_toolkit/pdf/General_Information/4334\%20Culturally\%20Inclusive\%20Environment_FINAL_20130418.pdf

[10] Shaping neighborhoods accessible London: achieving an inclusive environment. Supplementary planning guidance. URL: https:// www.london.gov.uk/sites/default/files/shaping_neighbourhoods_accessible_london_spg_2014.pdf 